\title{
PERFORMANCE ANALYSIS OF A SMALL-SCALE GRID-CONNECTED PHOTOVOLTAIC SYSTEM:A REAL CASE STUDY IN EGYPT
}

\author{
Hossam Abobakr ${ }^{* 1}$, Ahmed A. Zaki Diab ${ }^{2, *}$, Yahia B. Hassan ${ }^{3}$, and Ashraf A. M. Khalaf ${ }^{4}$ \\ ${ }^{1,2,4}$ Electrical Engineering Department, Faculty of Engineering, Minia 61111, Egypt \\ ${ }^{3}$ Higher Institute of Engineering, Minia 61111, Egypt \\ *Corresponding Author E-mail: enghossam841@gmail.com
}

\begin{abstract}
:
Renewable energy sources, especially PV systems, which become more significant sources of energy, are attracting considerable commercial interest. Nonetheless, the integration of the PV power plants to the utility grids may cause several operational problems for distribution networks. The severity of these problems directly depends on the percentage of PV penetration and the geography of the installation. Hence, knowing the possible impact of small gridconnected PV systems on distribution networks can provide feasible solutions before practical implementations in real-time. The electrical power generated from photovoltaic (PV) array depends mainly on the weather conditions. So, the PV solar grid-connected inverters should equip with the control system to meet a fast response of solar irradiance change. This study includes performance analysis for data and measurements which real-time from the PV gridconnected system site according to Egyptian PV-LV code-2014, simulation by using MATLAB/Simulink, and cost analysis for connecting small-scale $39.78 \mathrm{~kW}$ photovoltaic (SSPV) system to LV distribution networks. Power quality parameters are measured for the output of the installed PV system at the Holy Family School in Helwan, Egypt. The proposed system model is built on MATLAB/Simulink and simulated under daily weather conditions to test its operating performance. The power quality indices at the inverter output side have been measured using PA-9-plus power quality analyzer. The cost analysis of SSPV generator based on the weather conditions will lead to new investments. The system has been installed in October 2016, produces $68.966 \mathrm{MWh} /$ year annual energy yield, and reaches its initial cost in 6.2198 years. The produced electricity by the system is injected directly into the grid without storage devices (On-grid Plant).
\end{abstract}

Keywords: Photovoltaic system, Grid-connected, Power quality, Egyptian PV-LV code, Simulation, Cost analysis, Case study

\section{INTRODUCTION}

Renewable energy sources are used to improve the quality of power sources due to global warming and environmental conditions [1]. Moreover, variations in solar irradiation can cause power fluctuation and voltage flicker, resulting in undesirable effects on high penetrated PV systems in the power system [2]. The efficient and proper

Received:29 September, 2019, Accepted: 5 November, 2019 operation of photovoltaic systems are dependent on the fluctuation of solar irradiance; temperature and choice of power semiconductor devices are some of the parameters that affect the power quality of the grid-connected PV systems. Good power quality translates into obtaining a sinusoidal voltage and current output from the photovoltaic system; in order to avoid harmonics and eventually voltage distortion [3]. 
Economic incentives, reduction in cost, and the fast-technological developments allow the use of grid-connected PV plants in a simple, efficient and profitable way [4].

This paper specifies the performance analysis by recording measurements, simulation and cost analysis for connecting $39.78 \mathrm{~kW}$ PV system to low voltage (LV) distribution network. It presents and evaluate the measurements based on power quality quantities which are obtained from the PV grid-connected system site and the

MATLAB SIMULINK simulation. Power quality parameters (active power, reactive power, power factor, voltage, flicker, and total harmonic distortion) are measured from the output of the installed PV system over a period of three days at the considered set. The power quality of provided by the SSPV systems is governed by Egyptian standard (PV-LV code-2014) on voltage, flicker, frequency, harmonics and power factor (PF) at the point of common coupling (PCC).

The paper investigates the various effects for connecting SSPV systems to LV distribution networks by measuring PV array output, AC Side results and THD parameters for the output of the simulated PV system at the MATLAB SIMULINK. The paper discusses the cost analysis and breakeven point of SSPV system.

\section{GRID-CONNECTED PV SYSTEM DESCRIPTION}

\subsection{System Overview}

A $39.78 \mathrm{~kW}$ peak $(\mathrm{kWp})$ small-scale grid-connected PV system was installed at the Holy Family School in Helwan, Egypt as shown in Fig. 1. The main components of a SSPV power plant are PV modules, mounting (or tracking) systems, inverters, and the grid connection. The considered system consists of 3 main parts that are solar PV array, grid-connected inverter, and monitoring system. Table 1 shows the system overview.

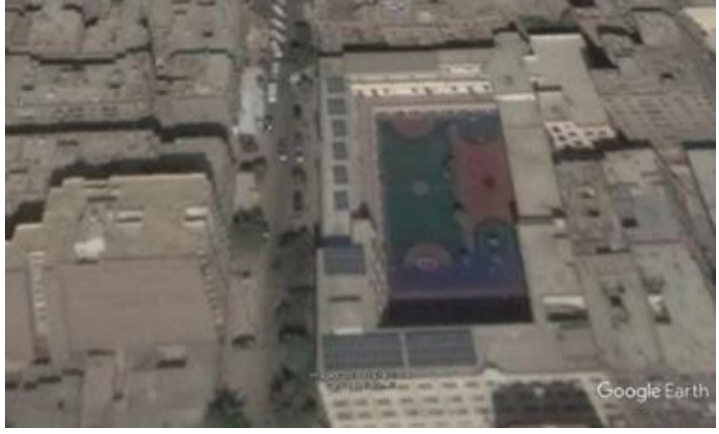

Fig. 1. Photo of the PV array on the School rooftop.

THE PROJECT INFORMATION

\begin{tabular}{|l|l|l|l|}
\hline Longitude & $\begin{array}{l}29^{\circ} 50^{\prime} \\
48.52\end{array}$ & Latitude & $\begin{array}{l}31^{\circ} 19^{\prime} \\
58.62\end{array}$ \\
\hline $\begin{array}{l}\text { Interconne } \\
\text { ction } \\
\text { voltage }\end{array}$ & $380 \mathrm{~V} / 220 \mathrm{~V}$ & Meter type & $\begin{array}{l}\text { Feeding } \\
\text { tariff }\end{array}$ \\
\hline $\begin{array}{l}\text { Peak } \\
\text { power }\end{array}$ & $39.78 \mathrm{~kW}$ & $\begin{array}{l}\text { Annual } \\
\text { Energy }\end{array}$ & $68,627 \mathrm{kWh}$ \\
\hline Tilt angle & 30 & $\begin{array}{l}\text { Mounting } \\
\text { structure }\end{array}$ & Fixed \\
\hline $\begin{array}{l}\text { Module } \\
\text { model }\end{array}$ & $\begin{array}{l}\text { Suntech } \\
\text { Power } \\
\text { STP255- } \\
\text { Inverter } \\
\text { model }\end{array}$ & $\begin{array}{l}\text { Sunny } \\
\text { Tripower } \\
\text { STP } \\
20 / \mathrm{Wd}\end{array}$ & $\begin{array}{l}\text { No000TL- } \\
30\end{array}$ \\
\hline $\begin{array}{l}\text { No. of } \\
\text { modules }\end{array}$ & 156 & $\begin{array}{l}\text { of } \\
\text { Inverters }\end{array}$ \\
\hline $\begin{array}{l}\text { No. of } \\
\text { strings }\end{array}$ & 8 & $\begin{array}{l}\text { No. of } \\
\text { modules } \\
\text { per strings }\end{array}$ & $20 / 4+19 / 4$ \\
\hline
\end{tabular}

\subsection{PV Modules}

The grid-connected PV system includes 156 multi-crystalline modules covering a total area of $400 \mathrm{~m}^{2}$. The electrical characteristics of each PV module are summarized in Table 2

PV MODULE ELECTRICAL CHARACTERISTICS AT STANDARD TEST CONDITION (STC).

\begin{tabular}{|l|l|}
\hline STC & STP255-20/wd \\
\hline Maximum Power at STC $\left(\mathrm{P}_{\max }\right)$ & $255 \mathrm{~W}$ \\
\hline $\begin{array}{l}\text { Maximum Operating Voltage } \\
\left(\mathrm{V}_{\mathrm{mp}}\right)\end{array}$ & $30.8 \mathrm{~V}$ \\
\hline $\begin{array}{l}\text { Maximum Operating Current } \\
\left(\mathrm{I}_{\mathrm{mp}}\right)\end{array}$ & $8.28 \mathrm{~A}$ \\
\hline Open Circuit Voltage $\left(\mathrm{V}_{\mathrm{oc}}\right)$ & $37.6 \mathrm{~V}$ \\
\hline Short Circuit Current $\left(\mathrm{I}_{\mathrm{sc}}\right)$ & $8.76 \mathrm{~A}$ \\
\hline Module Efficiency & $15.7 \%$ \\
\hline
\end{tabular}

\subsection{Grid-Connected Inverter}

The output terminals of the solar PV array are connected to a Sunny Tri power 
20000TL 3ph grid-connected inverter. This inverter is turned-on all-day time and automatically synchronizes to the electric grid. If the electric grid has a problem like shutdown or unusual problems, the inverter stops its operation for operator safety. Table 3 shows the Sunny Tri power 20000TL 3ph grid-connected inverter parameters. The electrical data are measured by the measurement function of the inverter. This inverter shows on its screen the PV system power transmitted to the electric grid, system voltage and amount of produced energy during the day and total runtime, etc.

Since the array voltage and current vary considerably depending upon the weather conditions, the inverter needs to move its working point to function optimally. To feed the maximum power into the electricity grid, the inverter must work at the maximum power point (MPP) of the PV array. The MPP tracker ensures that the inverter is adjusted to the MPP point and the great test possible power is fed into the mains electricity grid.

The efficiency of the solar inverter can be defined based on the values of electrical DC power delivered to the inverter from $\mathrm{PV}$ panels (PDC) and the AC power obtained from the inverter (PAC). The instantaneous inverter efficiency $\left(\eta_{i n v}\right)$ is defined as the ratio of output to input power:

$$
\eta_{i n v}=\frac{P_{A C}}{P_{D C}}
$$

The PV array efficiency $\left(\eta_{P V}\right)$ is calculated as:

$$
\eta_{P V}=\frac{P_{D C}}{G \times A}
$$

Where $A$ is the total active area of $\mathrm{PV}$ array, $m^{2}$.

$G$ is the total in-plane irradiance, $\mathrm{kw} / \mathrm{m}^{2}$.

The instantaneous reference yield $\left(y_{r}\right)$, which is the ratio of the total irradiance $\left(G\left(k W / m^{2}\right)\right)$ to the reference irradiance $\left(G_{s t c}=1 \mathrm{~kW} / \mathrm{m}^{2}\right)$, is given by

$$
y_{r}=\frac{G}{G_{s t c}}
$$

While the instantaneous array yield $\left(y_{A}\right)$, which is the ratio of the PV array output power $\left(P_{D C}\right)$ to the peak power $\left(P_{\max , s t c}\right)$ of the installed PV array.

$$
y_{A}=\frac{P_{D C}}{P_{\max , s t c}}
$$

The instantaneous $\left(y_{f}\right)$ can be calculated as follows:

$$
y_{f}=\frac{P_{A C}}{P_{\max , s t c}}
$$

The performance ratio is used to assess the quality of PV installation which is widely reported on a daily, monthly and yearly basis. The instantaneous performance ratio $\left(p_{r}\right)$, is expressed in percentage to describe the overall losses of the PV system output and can be defined by the following

\begin{tabular}{|c|c|}
\hline \multicolumn{2}{|l|}{ Input $(D C)$} \\
\hline Max. array power & $30000 \mathrm{Wp} \mathrm{STC}$ \\
\hline Max. DC voltage & $1000 \mathrm{~V}$ \\
\hline MPPT operating voltage range & $150 \mathrm{~V} \ldots 1000 \mathrm{~V}$ \\
\hline Min. DC voltage / start voltage & $150 \mathrm{~V} / 188 \mathrm{~V}$ \\
\hline Number of MPP tracker inputs & 2 \\
\hline $\begin{array}{l}\text { Max. operating input- current / per } \\
\text { MPP tracker }\end{array}$ & $66 \mathrm{~A} / 33 \mathrm{~A}$ \\
\hline $\begin{array}{l}\text { Max. short circuit current per } \\
\text { MPPT / string input }\end{array}$ & $53 \mathrm{~A} / 53 \mathrm{~A}$ \\
\hline \multicolumn{2}{|l|}{ Output $(A C)$} \\
\hline AC nominal power & $20000 \mathrm{~W}$ \\
\hline Max. AC apparent power & $20000 \mathrm{VA}$ \\
\hline Output phases / line connections & $3 / 3-N-P E$ \\
\hline Nominal AC voltage & $480 / 277$ V WYE \\
\hline AC voltage range & $244 \mathrm{~V} \ldots 305 \mathrm{~V}$ \\
\hline Rated AC grid frequency & $50 \mathrm{~Hz}$ \\
\hline AC grid frequency / range & $\begin{array}{l}50 \mathrm{HZ}, 60 \mathrm{HZ} / \\
-6 \mathrm{HZ} \ldots+5 \mathrm{HZ}\end{array}$ \\
\hline Max. output current & $24 \mathrm{~A}$ \\
\hline $\begin{array}{l}\text { Power factor at rated power / } \\
\text { adjustable displacement }\end{array}$ & $\begin{array}{l}1 \text { / } \\
\text { leading...0.0 } \\
\text { lagging }\end{array}$ \\
\hline Harmonics & $<3 \%$ \\
\hline
\end{tabular}
equations:

$$
P_{r}=\frac{y_{f}}{y_{r}}
$$

\section{GRID-CONNECTED INVERTER PARAMETERS}




\subsection{Monitoring and Data Acquisition System}

Figure 2 shows a photo for the used monitoring and data acquisition system. The figure shows PA-9 plus power quality analyzer was connected to the output of PV power plants at PCC. All real-time electrical data are logged into this monitoring system. PA-9 plus power quality analyzer Trends voltage, current, imbalance, power, energy, events, flicker (PST/PLT), THD, TDD, individual harmonics, and frequency according to standards (EN50160, IEC61000-4-15, IEEE1159/519)

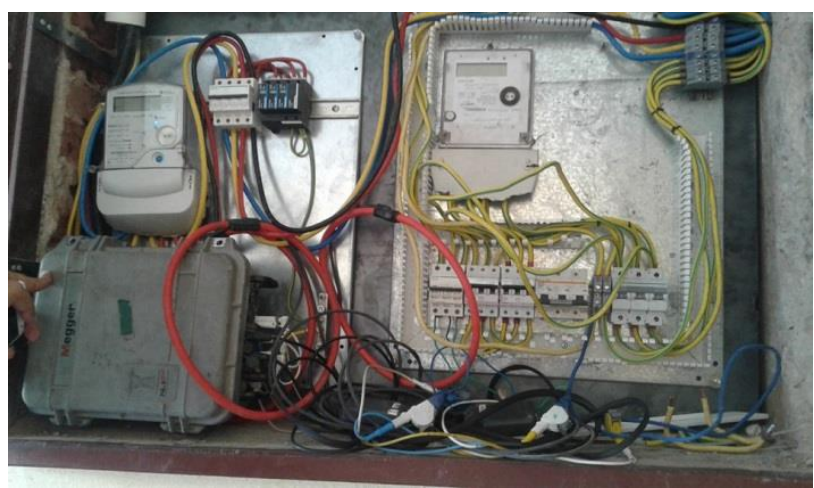

Fig.2. Photo of PA-9 plus Power Analyzer.

\subsection{Single Line Diagram (SLD)}

The PV array is divided into four strings. Moreover, each string is connected through an inverter with an average PV output voltage $600 \mathrm{~V}$. Two strings are built from interconnecting of 20 panels in series connected to input $\mathrm{A}$ and two strings are built from interconnecting 19 panels in series connected to input B for each inverter. The system overview is shown in Table 4.

The outputs of the strings are pooled in the array combiner box through DC fuses. A surge protector is incorporated in the system for transient protection and as a DC disconnect switch. The output of the array is brought to the control room, where the DC power is fed to the power conditioning unit.
$20 \mathrm{~kW}$ Sunny Tri power inverter, that includes filters, maximum power point tracking and control unit, is used to convert the DC PV power into AC power (three phase-four wire), $380 \mathrm{~V}, 50 \mathrm{~Hz}$ and to synchronize it with the utility grid (UG). The output of the inverter can follow the grid voltage, frequency, phase sequence, and phase shift during its normal operation. A single line diagram of the set-up gridconnected system is shown in Fig. 3 which show the PV power quality monitoring system is set around PA-9 plus power quality analyzer.

GRID-CONNECTED INVERTER PARAMETERS

\begin{tabular}{|l|l|l|}
\hline$P V$ design data & Input A & Input B \\
\hline $\begin{array}{l}\text { Suntech Power } \\
\text { STP255-20/Wd }\end{array}$ & 40 & 38 \\
\hline Azimuth / Tilt angle & $0^{\circ} / 30^{\circ}$ & $0^{\circ} / 30^{\circ}$ \\
\hline Number of Strings & 2 & 2 \\
\hline PV modules per string & 20 & 19 \\
\hline Peak power input & $10.2 \mathrm{kWp}$ & $9.69 \mathrm{kWp}$ \\
\hline Typical PV Voltage & $539 \mathrm{~V}$ & $512 \mathrm{~V}$ \\
\hline Min. PV Voltage & $502 \mathrm{~V}$ & $477 \mathrm{~V}$ \\
\hline Min. DC Voltage & $150 \mathrm{~V}$ & $150 \mathrm{~V}$ \\
\hline Max. PV voltage & $797 \mathrm{~V}$ & $758 \mathrm{~V}$ \\
\hline Max. DC voltage & $1000 \mathrm{~V}$ & $1000 \mathrm{~V}$ \\
\hline Max. current & $16.5 \mathrm{~A}$ & $16.5 \mathrm{~A}$ \\
\hline Max. DC current & $33 \mathrm{~A}$ & $33 \mathrm{~A}$ \\
\hline
\end{tabular}

This analyzer is designed as a universal meter for the entire field of power electronics and network analysis. It can be used practically in all power electronics applications, systems testing, and quality assurance. It can be used for measurements in motors, transformers, conventional and switched power supply units. The monitored results are collected using $1 \mathrm{~s}$ step. The recorded data are exported and averaged every $10 \mathrm{~min}$ and stored on the hard disk for analysis and evaluation. 


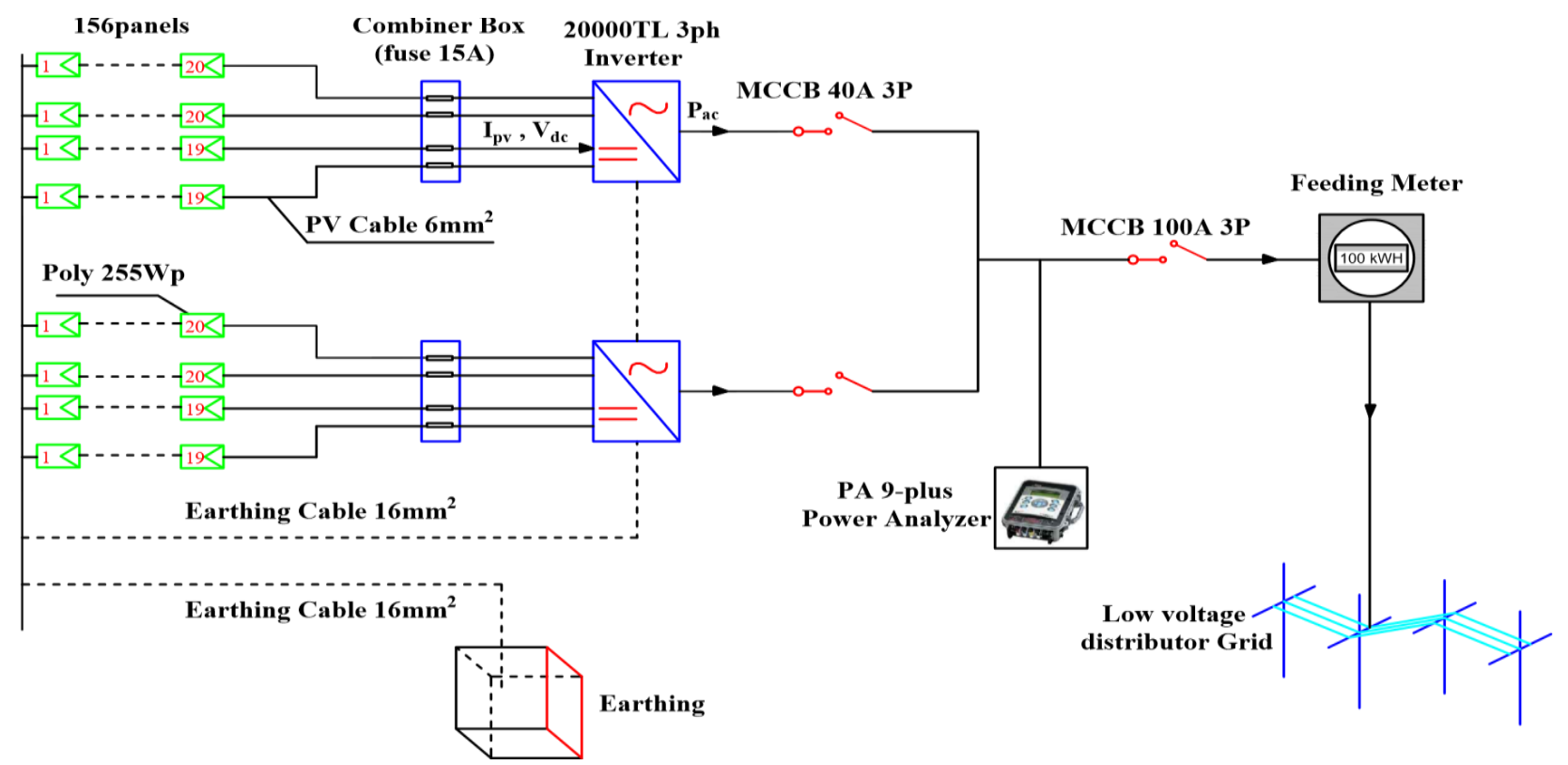

Fig.3. The single line diagram (SLD) of the SSPV.

\section{SYSTEM MODELLING}

The MATLAB SIMULINK model consists of $156 \mathrm{PV}$ arrays of solar panel STP255-20/wed, the DC-DC boost converter for boosting the PV voltage to a level that is adequate for the inverter to produce a maximum output voltage, a three-phase VSI connected between DC link capacitor (i.e. acts as a temporary power storage device to provide the VSI with a steady flow of power) and LC filter to prevent harmonics from propagating into the UG. The normal PV voltage is $290 \mathrm{Vdc}$ at a solar irradiance of $1000 \mathrm{~W} / \mathrm{m} 2$, which sets up to $500 \mathrm{Vdc}$ via DC-DC boost converter and then converted into AC voltage by a three-level VSI up to $20 \mathrm{kV}$ through a step-up transformer to inject to the grid.

\subsection{Modeling of PV ARRAY}

The modules of PV array are connected in series and parallel manner to give rated power. The 'Module' parameter of the PV Array block allows you to choose among various array types of the NREL System Advisor Model.

The manufacturer specifications for one module are:

- Number of cells per module: $\mathrm{N}_{\text {cell }}$ $=60$

- Open-circuit voltage: $\mathrm{V}_{\mathrm{OC}}=37.5 \mathrm{~V}$
- Short-circuit current: $\mathrm{I}_{\mathrm{SC}}=8.73 \mathrm{~A}$

- Voltage and current at maximum power: $\mathrm{V}_{\mathrm{mp}}=30.9 \mathrm{~V}, \mathrm{I}_{\mathrm{mp}}=8.26 \mathrm{~A}$

Figure 4 illustrates the electrical circuit of the PV array based on accurate two diode model $R_{S}(N s / N p)$.

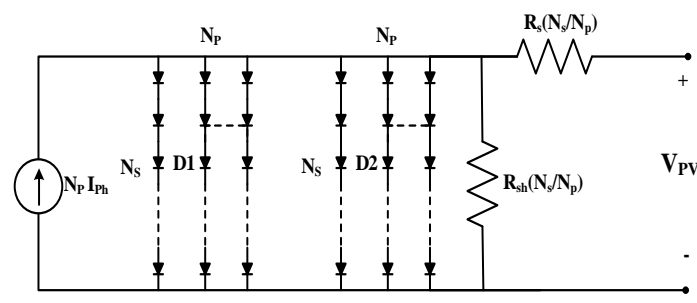

Fig. 4. The equivalent circuit of the single diode model for PV array.

The output current $\left(I_{P V}\right)$ of the PV array is given by[5]:

$$
\begin{gathered}
I_{P V}=N_{p} I_{p h}-N_{p} I_{s 1}\left[\operatorname { e x p } \left(\frac { 1 } { a _ { 1 } V _ { T } } \left(\frac{V_{P V}}{N_{s}}\right.\right.\right. \\
\left.\left.\left.+\frac{I_{P V} R_{s}}{N_{s}}\right)\right)-1\right] \\
-N_{p} I_{s 2}\left[\exp \left(\frac{1}{a_{2} V_{T}}\left(\frac{V_{P V}}{N_{s}}+\frac{I_{P V} R_{s}}{N_{S}}\right)\right)-1\right]- \\
\left.\frac{1}{R_{S h}}\left(\frac{V_{P V}}{N_{s}}+\frac{I_{P V} R_{S}}{N_{S}}\right)\right]
\end{gathered}
$$

where: 
$I_{s 1}$ is the saturation current of diode $D_{1}$.

$I_{s 2}$ is the saturation current of diode $D_{2}$

$V_{T}$ is the thermal voltage $\left(V_{T}=N S \frac{K T}{q}\right)$

$k$ is the Boltzmann constant,

$T$ is the absolute temperature in degrees Kelvin

$q$ is the electronic charge $(1.6 * 10-19 \mathrm{C})$

$a_{1}$ is idealist factor of diode $D_{1}$

$a_{2}$ is idealist factor of diode $D_{2}$

$V_{P V}$ is the output voltage of the PV array

$R_{S}$, and $R_{s h}$ are series and shunt resistances of PV cells

$N_{s}$ and $N_{p}$ are the number of series and parallel cells, respectively $I_{p h}$

\section{2.. Modeling of DC-DC Boost Converter}

Figure 5 shows the configuration of the DC-DC boost converter. Moreover, output and input relations of the DC-DC boost converter during continues mode operation are given as follows [6-8]:

$$
\begin{aligned}
& V_{D C}=\frac{V_{P V}}{1-D} \\
& L_{\text {boost }}=\frac{V_{P V}\left(V_{D C}-V_{P V}\right)}{\Delta i_{L b o o s t} f_{s} V_{D C}} \\
& C_{B}=\frac{\Delta i_{L}}{8 f_{S} \Delta V_{P V}} \\
& C_{D C}=\frac{P_{P V}}{2.0 w_{g} V_{D C} \Delta V_{D C}}
\end{aligned}
$$

Where:

$\Delta i_{L}$ boost is the amplitude of ripple boost inductor current $\quad 1.4 \%$,

$f_{s}$ is the switching frequency of the boost converter power switch.

$V_{D C}$ is the main voltage across the DC capacitor $=500 \mathrm{~V}$.

$\Delta V_{P V}$ is the amplitude of ripple PV output voltage $=0.4 \%$.

$P_{P V}$ is the rated power of PV system = $100 \mathrm{~kW}$.

$w_{g}$ is the utility grid angular frequency in $\mathrm{rad} / \mathrm{sec}=314.0 \mathrm{rad} / \mathrm{s}$. $\triangle V_{D C}$ is the amplitude of ripple capacitor voltage $=10 \%$,

The DC-DC boost converter parameters are computed

from Eqs. (8:11).

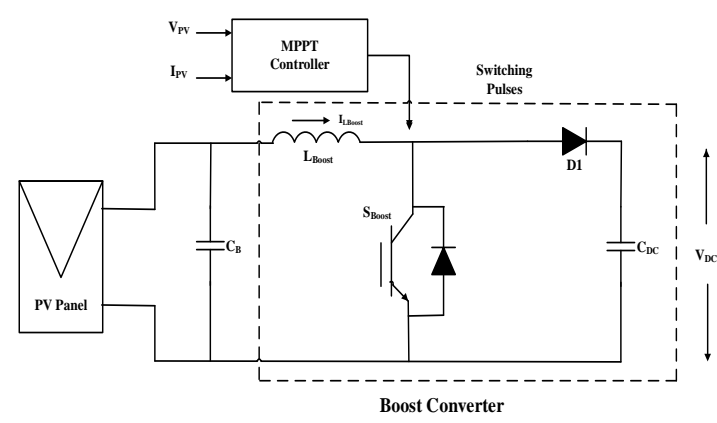

Fig.5. DC-DC boost converter with its controller.

\subsubsection{Power Filter}

The UG interface contains filters to reduce the harmonics generated by the inverter and to neutralize spikes coming from the UG [9]. Figure 6 shows the model of power filter considered in this system. The filter is a three-phase passive filter of second-order low pass filter and installed at the output of three phases VSI.

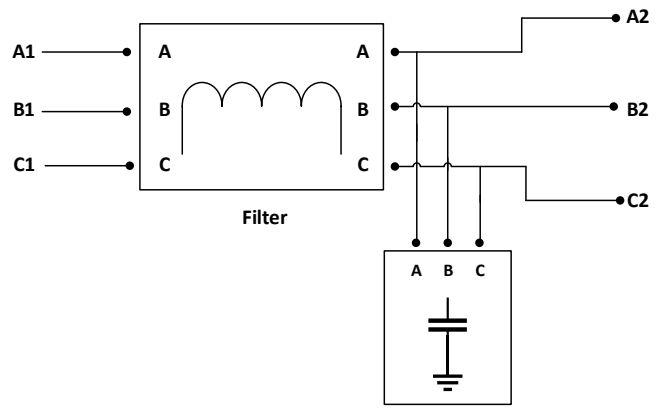

Fig.6. LC power filter model connected at the output of PV inverter.

The selection of the capacitor is a tradeoff between reactive power supplied by the capacitor at the fundamental frequency and coil inductance. The increasing capacitance value will reduce the efficiency of the inverter while reducing the capacitance value of LC filter will increase the inductor and its voltage drop across the network. Normally the reactive power of the capacitor is 
suggested less than $15 \%$ of the rated inverter power. In such a design, the reactive power is chosen as $10 \%$ of the rated power of the inverter [10].

$$
C_{f}=10 \%\left(P_{P V} /\left(3 * 2 \pi f_{g} V_{g}^{2}\right)\right)
$$

The selection of filter inductance $L_{f}$ depends on the resonance frequency of the filter that is should be greater than or equal to 10th of the grid frequency to avoid resonance with the grid network. So, the filter inductance is expressed as:

$$
L_{f} \leq \frac{1}{100 w_{g}^{2} C_{f}}
$$

Total harmonic distortion (THD) ratio of the RMS value of the harmonics to the RMS value of the fundamental and is defined as:

$$
T H D_{i}=\frac{\sqrt{\sum_{i=2}^{n} X_{n}^{2}}}{X_{1}}
$$

where,

$x_{n}$ is the r.m.s. of the harmonic voltage or current of the order $n$

$X_{1}$ is the r.m.s. of the fundamental voltage or current

\subsubsection{Modeling of VSI}

Voltage source inverter (VSI) is used to convert the DC PV power into AC power that is injected to the UG. The DC-AC power conversion process is carried out with the aid of a three-level voltage source inverter (3L-VSI). The advantages of such inverters are for $[11,12]$, improving voltage quality [13], reducing conduction loss and switching frequency, lowering blocking voltage and voltage tresses $(d v / d t)$ on power switches. The simplified schematic diagram of a single leg of a three-level capacitor clamped VSI is shown in Fig. 7.

Table 5 lists the output voltage levels for one phase of the inverter. The state condition 1 means the switch is $\mathrm{ON}$, and 0 means the switch is OFF.

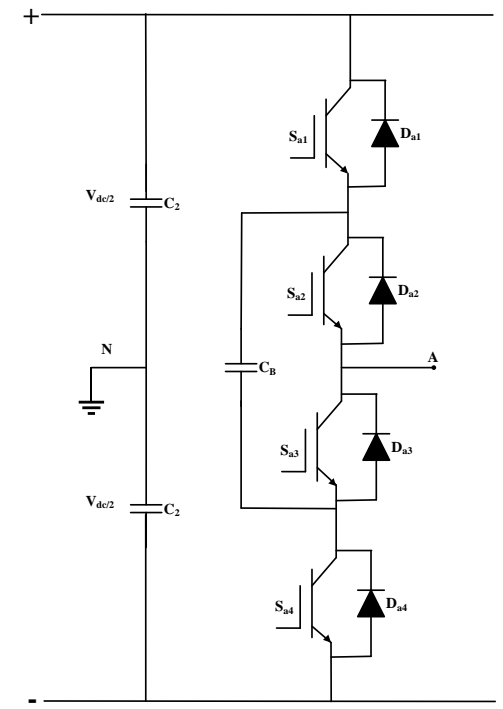

Fig. 7. Simple single leg of a three-level VSI.

SWITCHING STATES OF 3L-VSI

\begin{tabular}{|c|c|c|c|c|}
\hline \multirow{2}{*}{$\begin{array}{c}\text { Pole } \\
\text { voltage, } \\
\text { Va0 }\end{array}$} & \multicolumn{4}{|c|}{ Switch State } \\
\cline { 2 - 5 } & $\boldsymbol{S a \boldsymbol { 1 }}$ & $\boldsymbol{S a 2}$ & $\boldsymbol{S a 3}$ & $\boldsymbol{S a 4}$ \\
\hline $\mathrm{Vdc} / 2$ & 1 & 1 & 0 & 0 \\
\hline 0 & 0 & 1 & 1 & 0 \\
\hline $\mathrm{Vdc} / 2$ & 0 & 0 & 1 & 1 \\
\hline
\end{tabular}

\subsubsection{MPPT control system}

The MPPT controller uses the P\&O MPPT algorithm of the PV panel voltage and current. Figure 8 illustrates the flowchart of the MPPT P\&O modified algorithm $[14,15]$. The flowchart shows that, at each sampling period, the MPP can be tracked by comparing the change in power, voltage and load demand with respect to zero to get the correct direction for perturbing the PV array voltage, $V_{P V}$ to locate the MPP quickly where $V_{P V}$, equals to $V_{m p p}$ at MPP. Once the MPP is reached, the operation of the PV array is maintained at this point unless there is change in $\Delta P$, which indicates a change in solar radiation or weather condition. The algorithm decreases or increases $V_{P V}$ to track the new MPP [14, 15]. This method provides better tracking of the MPP under fastchanging atmospheric conditions as compared with the conventional $\mathrm{P} \& \mathrm{O}$ method. 


\subsection{Control of Grid-Connected Inverter}

Figure 9 shows the control scheme of VSI. A PLL is used to synchronize the inverter with the grid, where it takes the grid voltage and gives the frequency and phase angle of the grid voltage correctly even with distortion in the grid voltage [16]. The system control is composed of voltage and current regulators to improve the power factor and satisfy the synchronization requirements of the inverter with the UG in the synchronous frame. The Voltage Regulator minimizes variation in the DC voltage due to the change of the weather conditions via the PI controller. Voltage regulator generates command current $I_{d}^{*}$ to process of its current regulator through comparing the measured DC voltage with setting DC voltage $V_{d c}^{*}$ The current regulator consists of PI controllers for both $i_{d}$ and $i_{q}$ currents. The command current $I_{d}^{*}$ is drawn from Voltage regulator and compared with the grid current $I_{d}$.

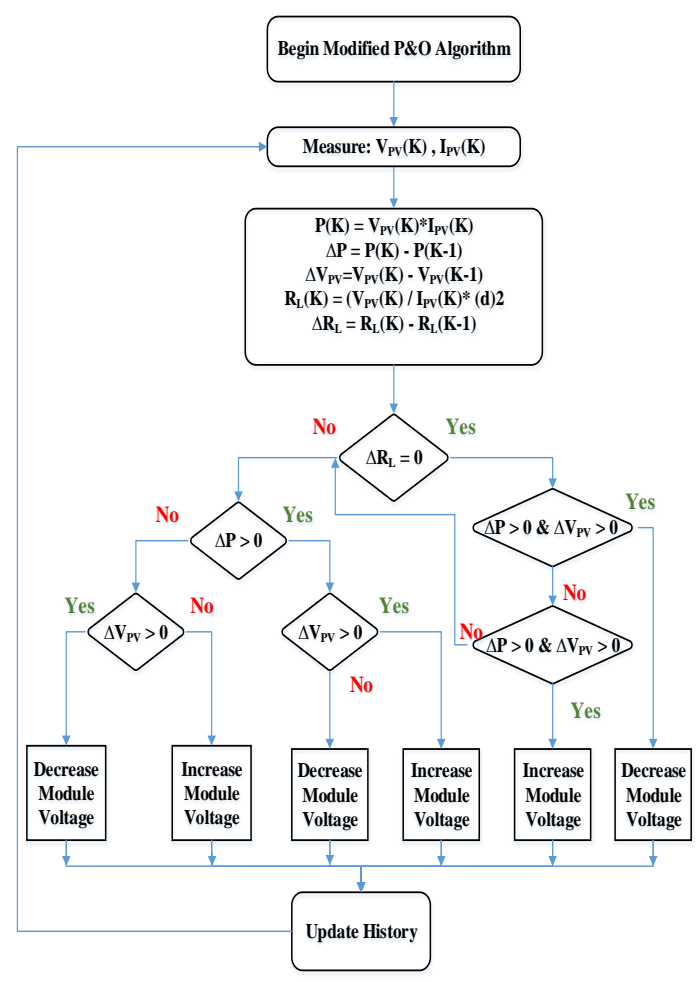

Fig.8. Flowchart of the P\&O MPPT algorithm.

The compared signal $\left(\Delta I_{d}\right)$ is processed through the PI controller for minimizing the error and producing, adding signal with generated voltage measuring signal $\left(V_{d}\right)$ to compare with $\omega_{L}$ to produce $V_{d}^{*}$ command. Also, the command current $I_{q}^{*}$ is equal to zero to improve the power factor of inverter up to unity. The signal $\left(\Delta I_{q}\right)$ is processed through the PI controller to produce adding signal with generated voltage $\left(V_{q}\right)$ and $\omega L$ to produce $V_{q}^{*}$ command. The outputs of the PI controllers are processed through the hysteresis band to limit the errors between upper and lower limits. The $(d q 0)$ is converted into the three-phase $(a b c)$ to PWM.

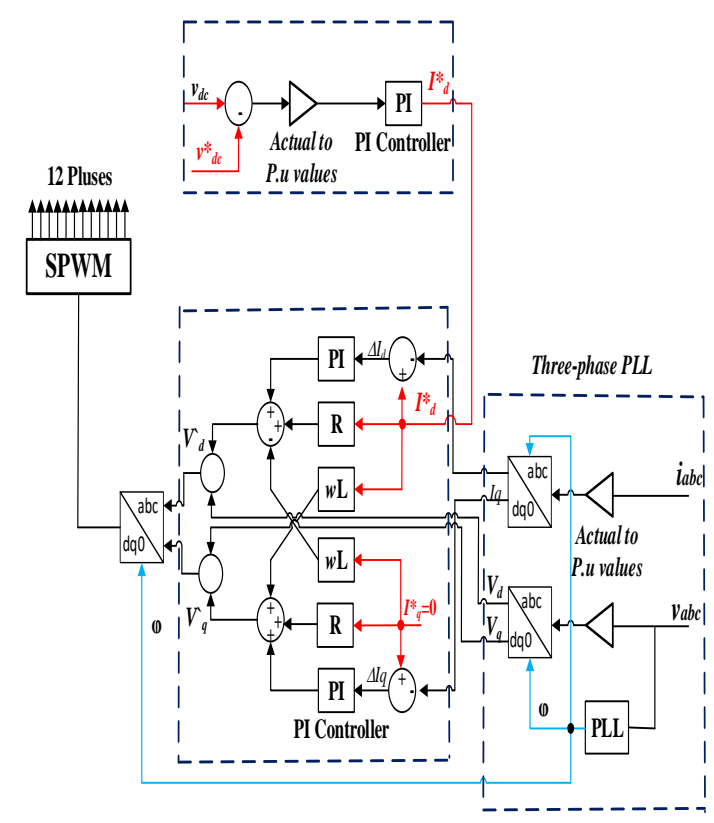

Fig.9. Control scheme for three-phase grid-connected VSI.

\section{DISCUSSION AND RESULTS}

\subsection{Evaluated the recorded measurements of the SSPV according to Egyptian PV- LV code- 2014}

Power quality parameters are measured for the output of the installed PV system at the considered site by using PA-9 plus power quality analyzer at PCC. The power quality parameters recorded are the active power, voltage, reactive power, power factor, flicker and THD are measured as well over a period from $01 / 11 / 2016$ at $10: 14$ to $03 / 11 / 2016$ at 18:04. The power quality provided by the SSPV systems is governed by practices and standards according to the Egyptian PV-LV code. 
Figure 10 (a) shows the active power injected to UG which has a fluctuating during sun hours (from sunrise to sunset).
Table 6 evaluates the recorded measurements according to the Egyptian PV-LV code.

TECHNICAL REQUIREMENTS OF SSPV BASED ON EGYPTIAN PV-LV CODE-2014

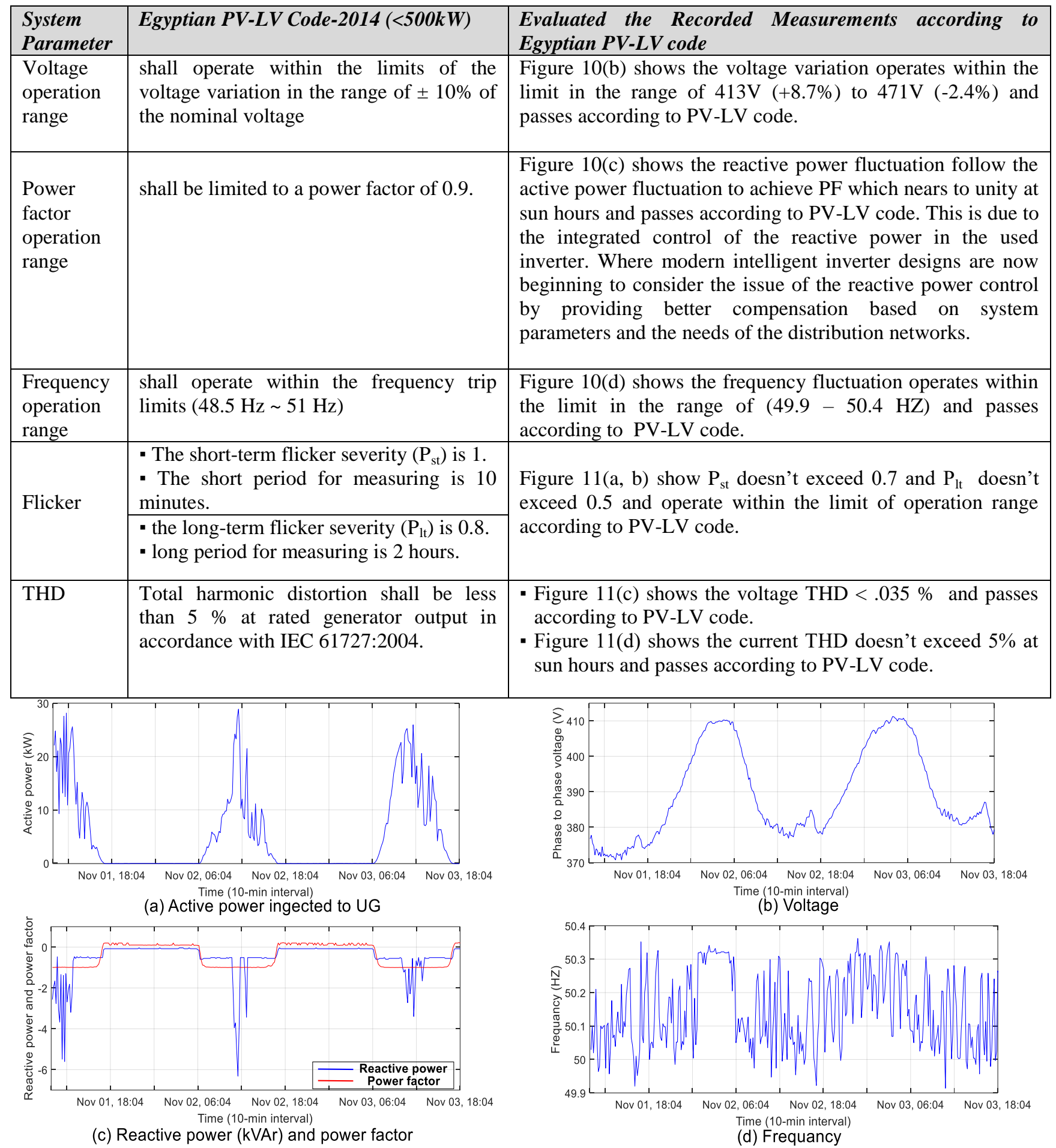

Fig.10. The active power, voltage, power factor, frequency records (Measurements). 


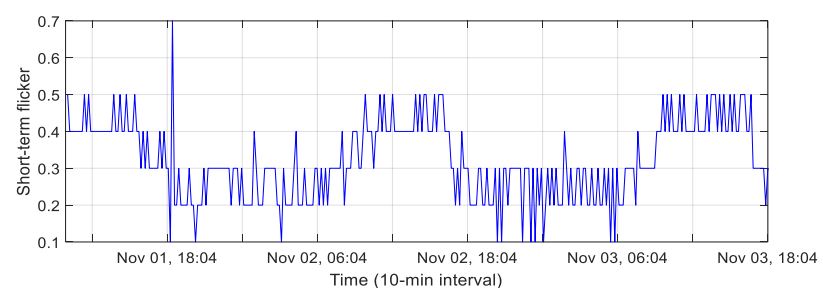

(a) Short-term flicker

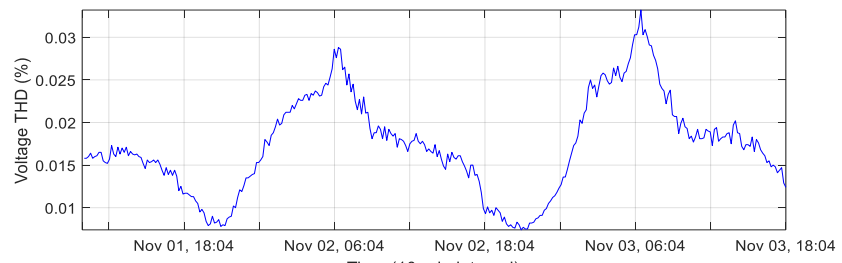

(c) Voltage THD

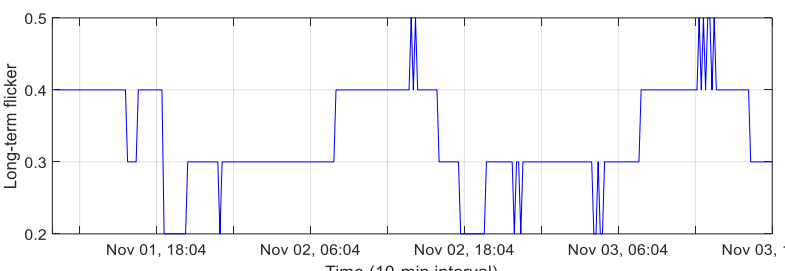

(b) Long-term flicke

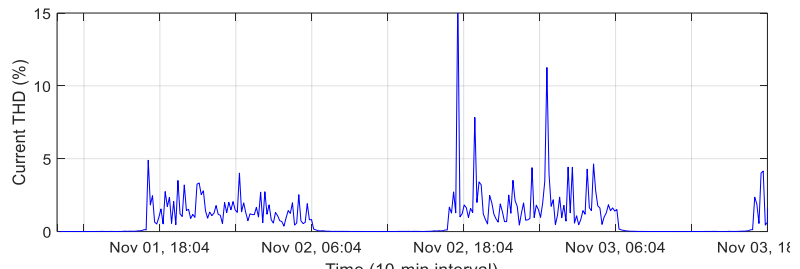

Time (10-min interval)
(d) Current THD

Fig.11.The flicker and THD (Measurements).

\subsection{Performance analysis of SSPV power quality based on Simulation}

To investigate the various effects for connecting SSPV system to LV distribution networks simulated $39.78 \mathrm{~kW}$ gridconnected PV system (likewise the real case) by MATLAB SIMULINK and measured PV system output parameters.

There are two cases, one with varying assumed solar irradiance values (fluctuating between $1000 \sim 500 \mathrm{~W} / \mathrm{m} 2$ ) and the other with actual solar irradiance that are obtained from statistics. The temperature is assumed constant $\left(25^{\circ} \mathrm{C}\right)$ in the two cases.

Case 1: This case is designed to compute the performance under variable solar irradiance ranging between $1000 \mathrm{~W} / \mathrm{m} 2$ and $500 \mathrm{~W} / \mathrm{m} 2$. A Simulink model is employed to estimate the effects of changing irradiance on a PV system.

Figure 12(a) shows the hypothetical solar radiation distribution over the day that categorized to sunrise, sunny, thin low start cloud, and sunset period. Figure 12(b, c, d) shows PV Side results. Figure 12(b) shows the PV array output power starts to appear as the radiation increased at 06:00 a.m. and reaches to a steady-state value of $37.75 \mathrm{~kW}$ when the radiation becomes $1000 \mathrm{~W} / \mathrm{m} 2$ at 8:00 a.m. After applying the MPPT algorithm at 9:50 the output power increased by about $4.84 \%$ to be $39.67 \mathrm{~kW}$. A low percentage of power increased due to MPPT as the duty cycle is adjusted to a value ( $D=$ 0.5) that gives the DC link voltage level directly. When the radiation deceased to 800 w/m2 during (10:15 to 12:00 a.m.) due to thin low stratus clouds, the output power also decreased to $32 \mathrm{~kW}$. If the radiation is further deceased to $500 \mathrm{w} / \mathrm{m} 2$ during (14:00 to $15: 00$ p.m.) due to larger clouds, the output power also decreased to $17.5 \mathrm{~kW}$. Figure 12(c) shows the simulated PV array voltage and current during the hypothetical solar radiation distribution. From this figure, the output voltage is still constant and PV current also is linear with solar irradiance. Figure 12(d) shows the duty cycle with and without applying algorithm MPPT which provides substantially more power as shown in Figs. 12(b) and13(a).

Figure 13 shows grid side results. Figure 13( $\mathrm{a}, \mathrm{b})$ shows that the active power which is injected into the grid, is linearly varied with the solar irradiance but the reactive power follows the active power to achieve the unity power factor. Figure 13(c) shows the simulated voltage and current waveforms of phase A before the transformer. From this figure, the voltage and current injected to the grid from the PV system at the PCC are in phase (unity power factor). Figure 13(d) shows the output voltage and zoom version of 3L-VSI before and after LC filter which reduces ripple content at the output.

Figures 14 and 15 show the voltage and current THD. The IEEE standard for THD is less than $5 \%$. THDs below $5 \%$ are widely considered to be acceptable, while values above $10 \%$ are unacceptable and will cause problems for sensitive equipment and loads. Figure 14 shows the voltage THD before and -88 - 
after the filter. It is noted that the installation of LC filter reduces the amount of THD from $89.13 \%$ to $0.8 \%$. Figure 15 shows the current THD versus harmonic order, simulated time and solar irradiance. From this figure, the

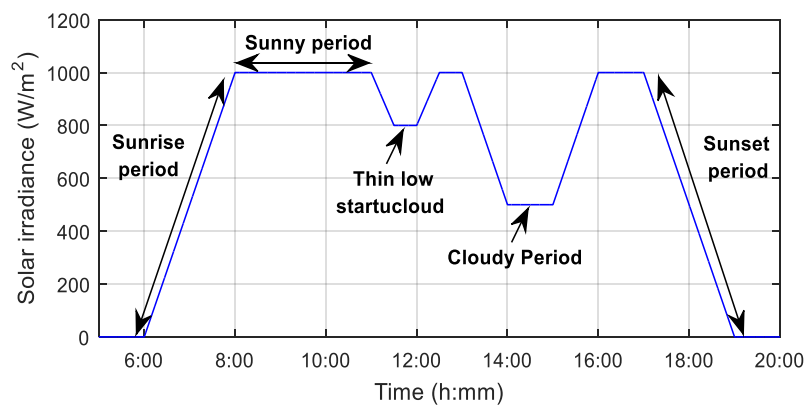

(a) Solar irradiance

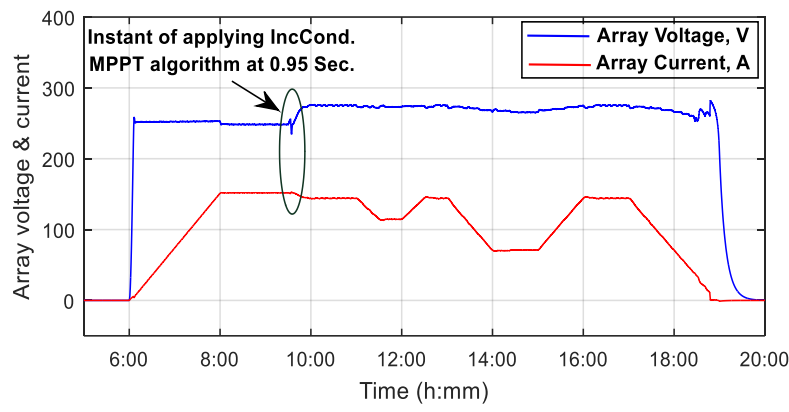

(c) Array Voltage and Current current THD decreases significantly at high solar irradiance conditions and increases at low solar irradiance. Current THD very sensitive to changes in incident radiation.

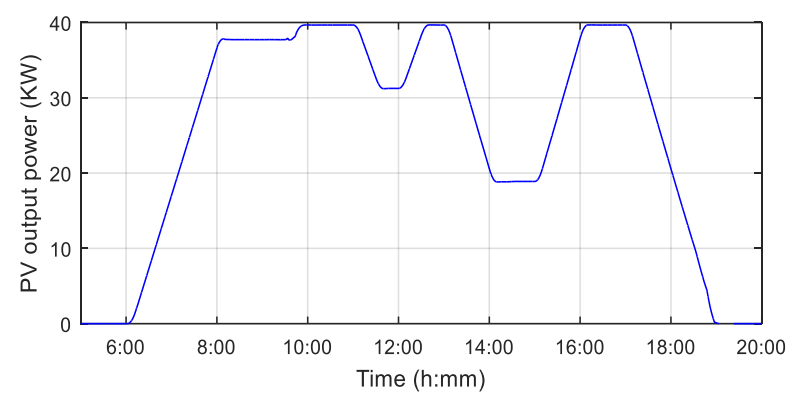

(b) PV output power

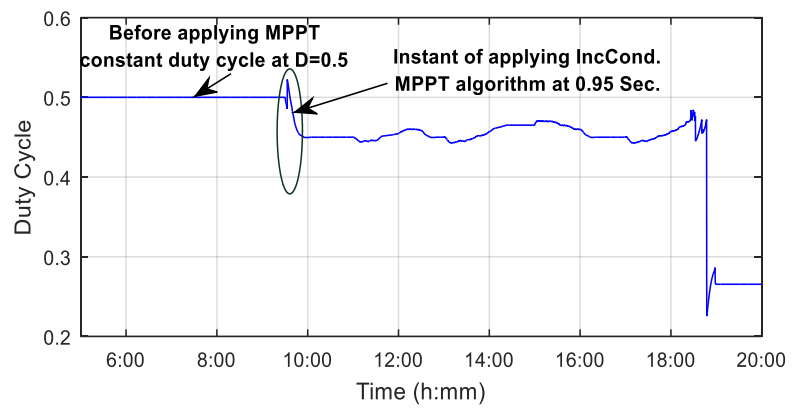

(d) Duty cycle with and without MPPT algorithm

Fig.12. The assumed solar irradiance and PV side results.

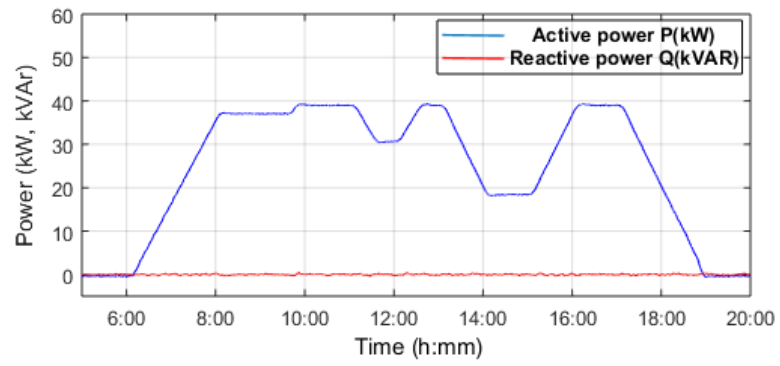

(a) Active and reactive power ingected to UG

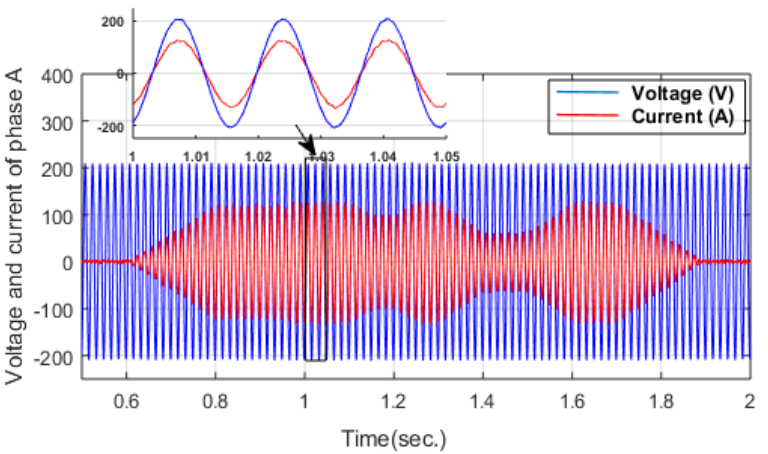

(c) Voltage and Current waveforms before transformer

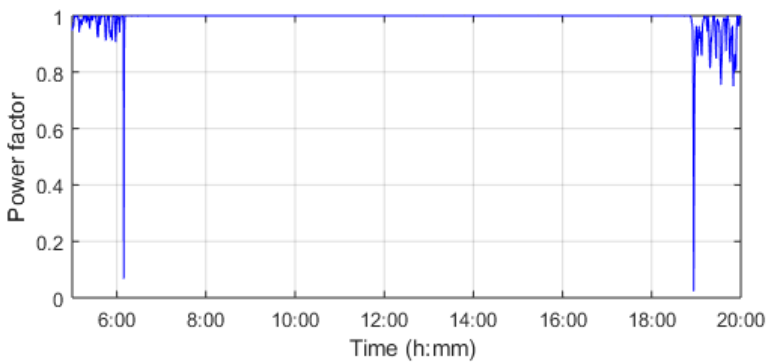

(b) Power factor

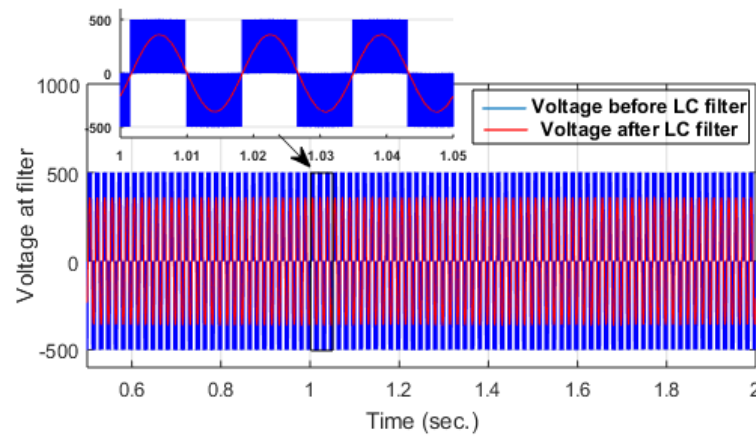

(d) Output Voltage of 3L-VSI before and after LC filter

Fig. 13. AC Side results for assumed irradiance. 

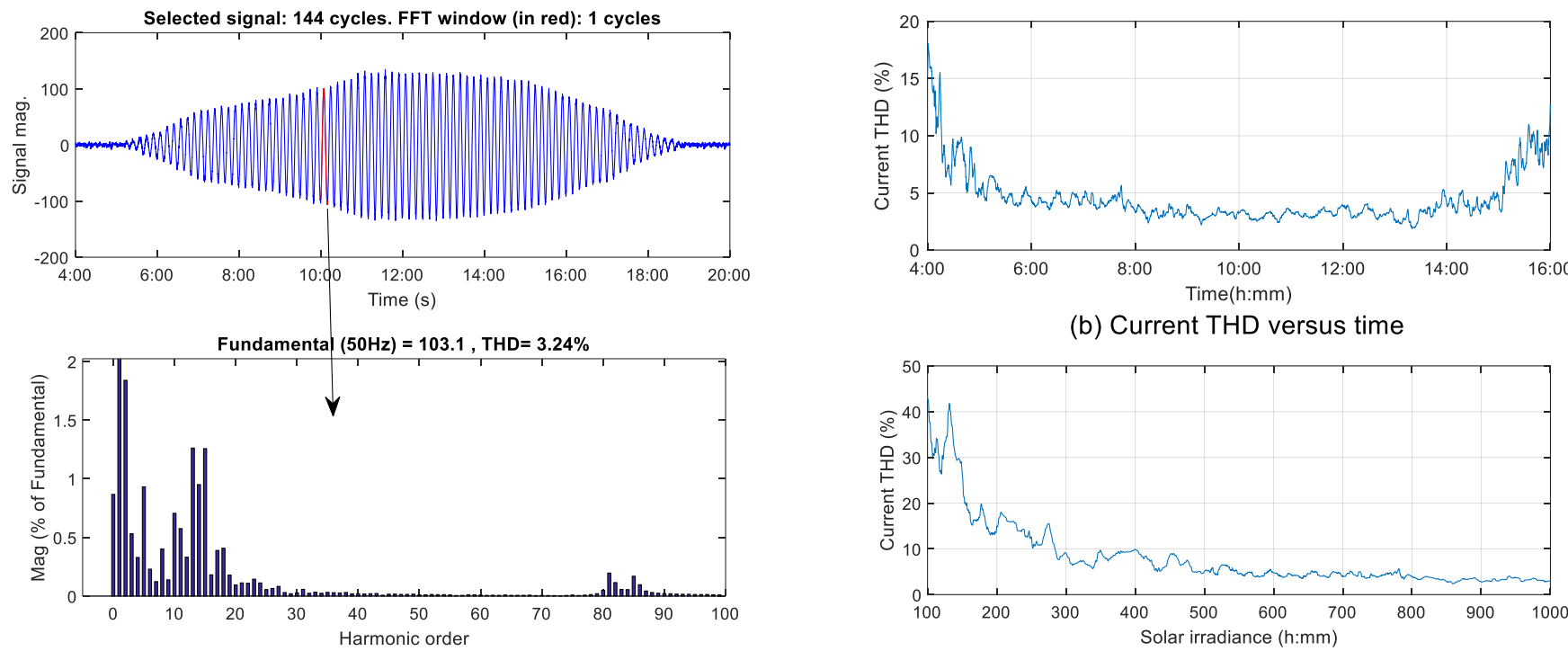

(b) Current THD versus time

(a) Current THD versus harmonic order

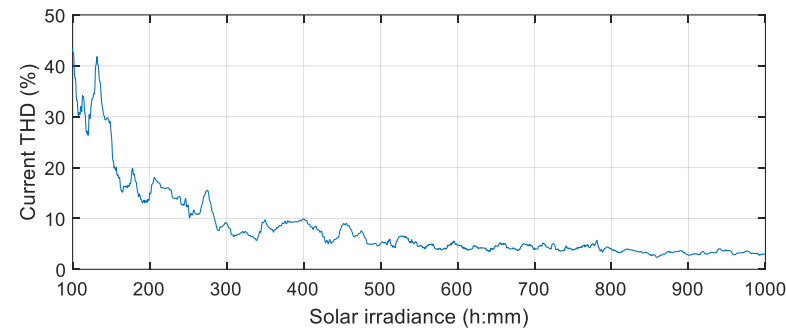

(c) Current THD versus solar irradiance

Fig. 14. Voltage THD before and after LC filter.
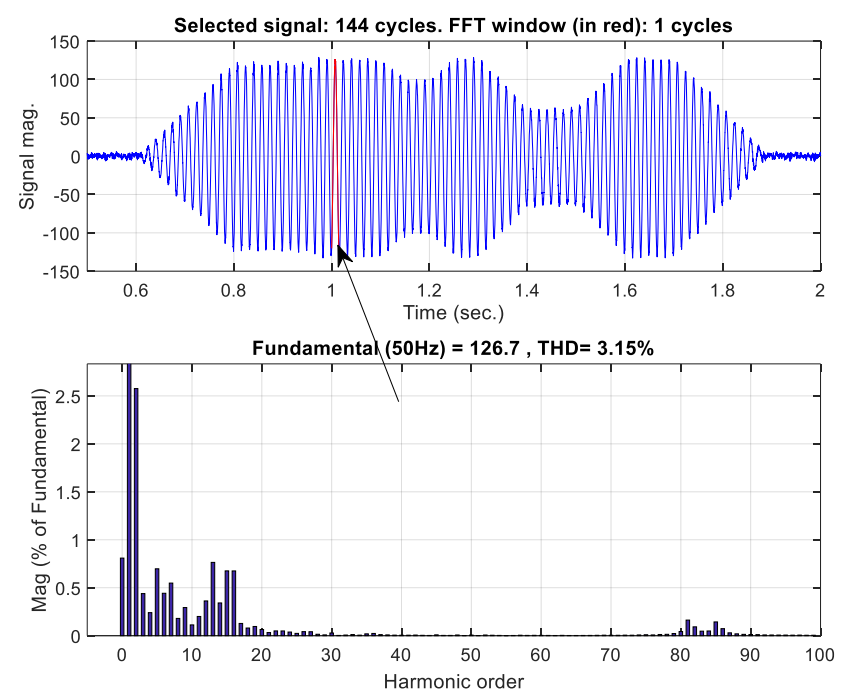

(a) Current THD versus harmonic order

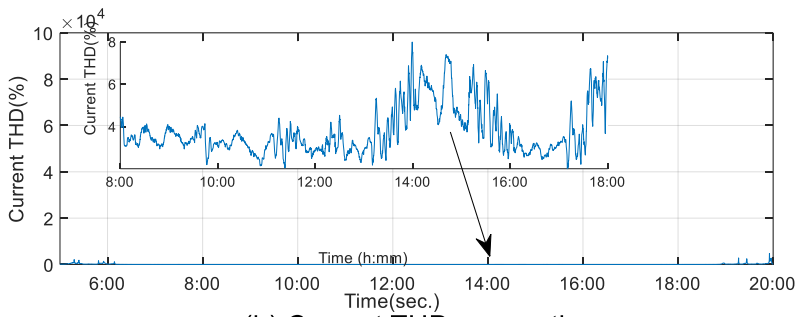

(b) Current THD versus time

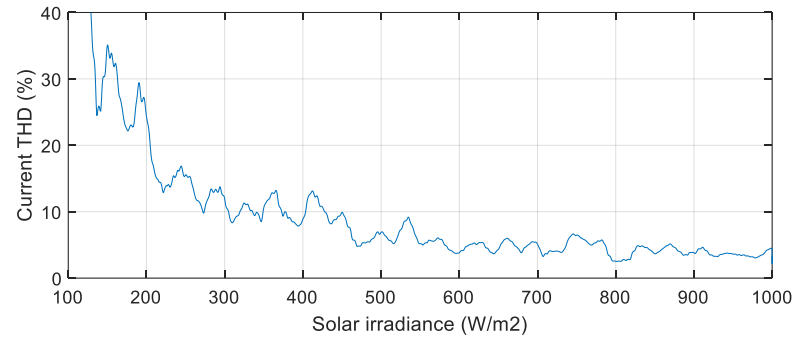

(c) Current THD versus solar irradiance

Fig. 15. The current THD.

Case 2: the second examined case is for actual solar irradiance for a day as shown in fig. 16(a).
Table 7 lists the simulation results and discusses PV sides results, grid side results, voltage THD and current THD as shown in Fig. 16, 17, 18 and 19 respectively. 
SiMULATION RESULTS OF CASE 2

\begin{tabular}{|c|c|}
\hline Parameters & Discuss Simulation results of case 2 \\
\hline $\begin{array}{ll}\text { PV } & \text { side } \\
\text { results } & \end{array}$ & $\begin{array}{l}\text { - Figure } 16(\mathrm{~b}) \text { shows the PV output array is strongly dependent on solar irradiance fluctuation. } \\
\text { - Figure } 16(\mathrm{c}) \text { shows the voltage and current array. From this figure, the PV current is strongly } \\
\text { dependent on solar irradiance, but the PV voltage is constant with irradiance variation. } \\
\text { - Figure } 16(\mathrm{~d}) \text { shows the actual voltage fluctuates to follow the reference voltage of MPPT algorithm. }\end{array}$ \\
\hline Active Power & $\begin{array}{l}\text { - Figure 17(a) shows The active power produced by the system is strongly dependent on solar } \\
\text { irradiance fluctuation. } \\
\text { - Fluctuations of solar irradiance lead to fluctuations of active power supplied to the distribution } \\
\text { network. } \\
\text { - when solar irradiance is low, the produced active power of PV unit is low. } \\
\text { - The active power delivered to the distribution network is found to vary linearly with the fluctuation } \\
\text { of the solar irradiance incident on the PV modules }\end{array}$ \\
\hline $\begin{array}{l}\text { Reactive } \\
\text { Power and } \\
\text { power factor }\end{array}$ & $\begin{array}{l}\text { - Figure } 17 \text { (a) shows the reactive power is dependent on the active power of the inverter for } \\
\text { maintaining the power factor to the accepted levels as shown in Fig. } 17(\mathrm{~b}) \text { which in turn is affected by } \\
\text { solar irradiance levels. This is due to the integrated control of the reactive power in the used inverter. } \\
\text { Where modern intelligent inverter designs are now beginning to consider the issue of the reactive } \\
\text { power control by providing better compensation based on system parameters and the needs of the } \\
\text { distribution networks. } \\
\text { - The results of the power factor are found to be acceptable for a large fraction of the day, but it can } \\
\text { also be observed that the power factor falls below the acceptable limits during the time of low solar } \\
\text { irradiance. } \\
\text { - The power factor is shown to act linearly for values of solar irradiance lower than } 200 \mathrm{~W} / \mathrm{m}^{2} \text { while } \\
\text { stays close to unity for the higher values. }\end{array}$ \\
\hline Voltage THD & $\begin{array}{l}\text { - A major power quality problem in power electronic converter applications results from the } \\
\text { voltage/current THD provided by the inverters. } \\
\text { - Figure } 18(\mathrm{a}) \text { shows the voltage THD doesn't exceed } 1.4 \% \text {. } \\
\text { - Figure } 18(\mathrm{c}) \text { and } 18(\mathrm{~d}) \text { show the voltage THD versus harmonic order before and after LC filter. From } \\
\text { these figures, it can be observed that the installation of LC filter reduces the amount of THD for } 3 \mathrm{~L}- \\
\text { VSI topologies from } 90.86 \% \text { to } 0.96 \% \text {. } \\
\text { - The harmonics generated by the inverter are reduced through the passive filter. }\end{array}$ \\
\hline Current THD & $\begin{array}{l}\text { - the current THD versus harmonic order is shown in fig. 19(a). } \\
\text { - the current THD increases significantly at low solar irradiance conditions in sunrise and sunset as } \\
\text { shown in Fig.19(b). } \\
\text { - the current harmonics (fig. 19(c)) are very sensitive to changes in incident radiation. These results } \\
\text { confirm that the high harmonic content has occurred at the low solar radiation values. }\end{array}$ \\
\hline
\end{tabular}


Vol. 40, No. 1. January 2021

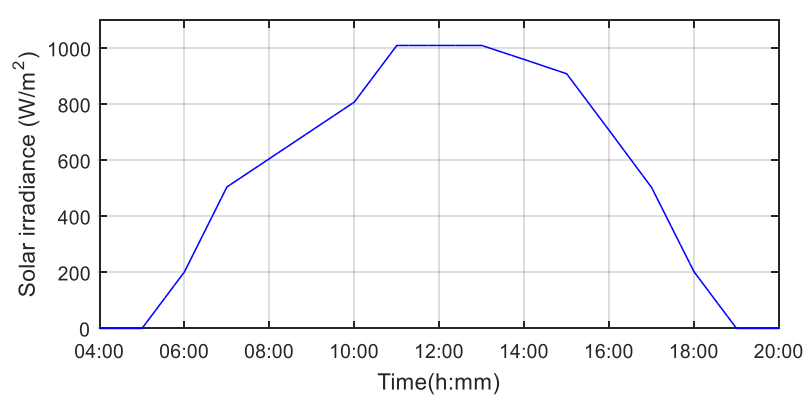

(a) Solar irradiance

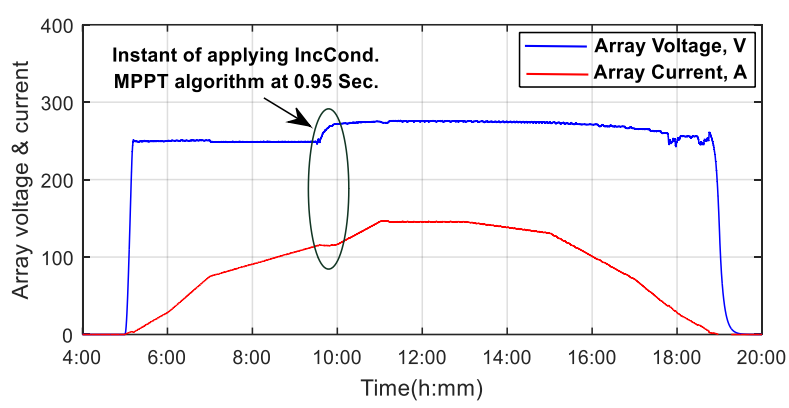

(c) Array Voltage and Current

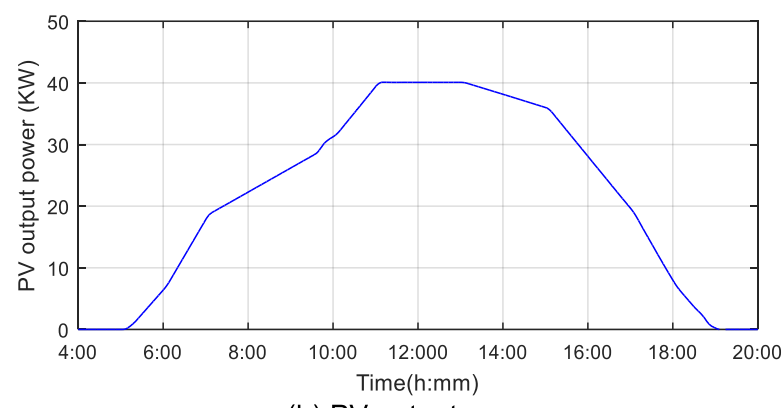

(b) PV output power

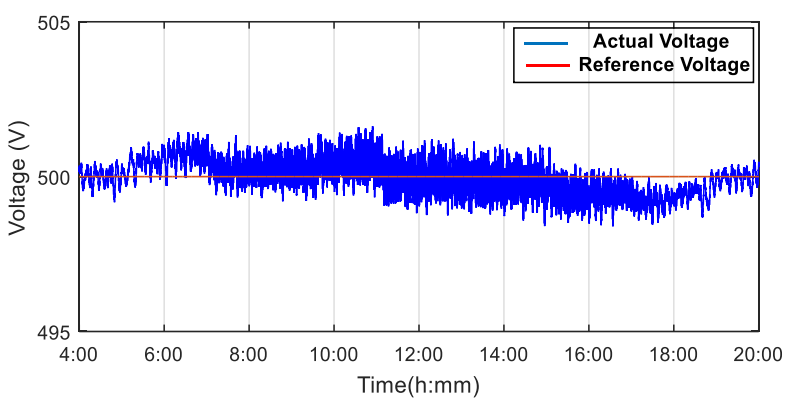

(d) Actual and reference dc voltage input to the inverter

Fig. 16. Actual irradiance and PV side results.

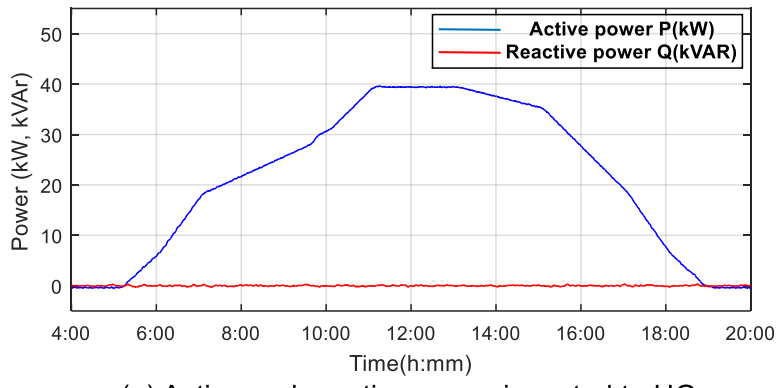

(a) Active and reactive power ingected to UG

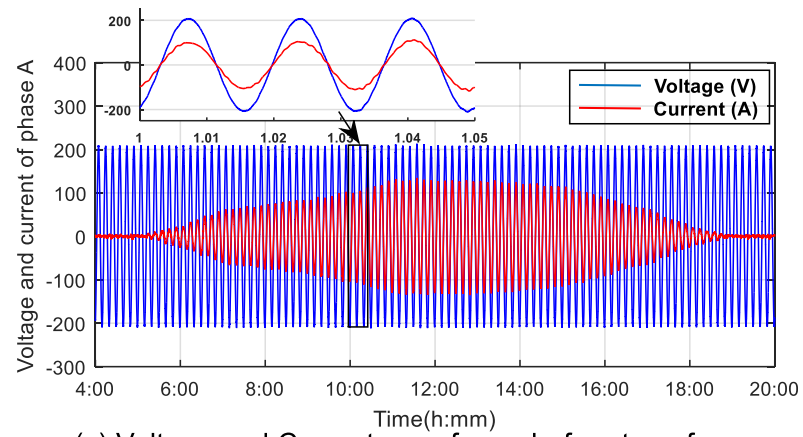

(c) Voltage and Current waveforms before transformer

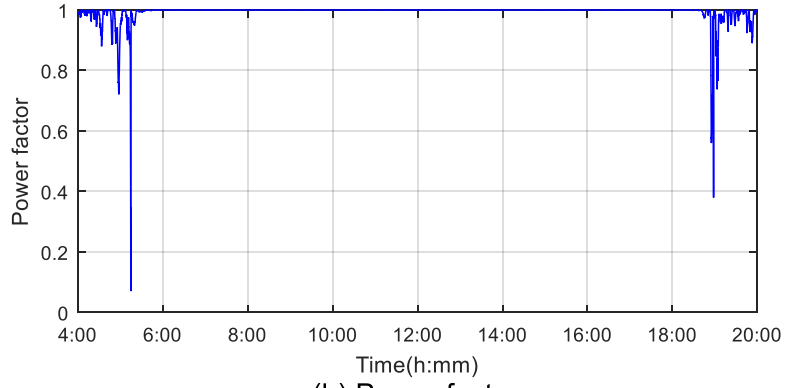

(b) Power factor

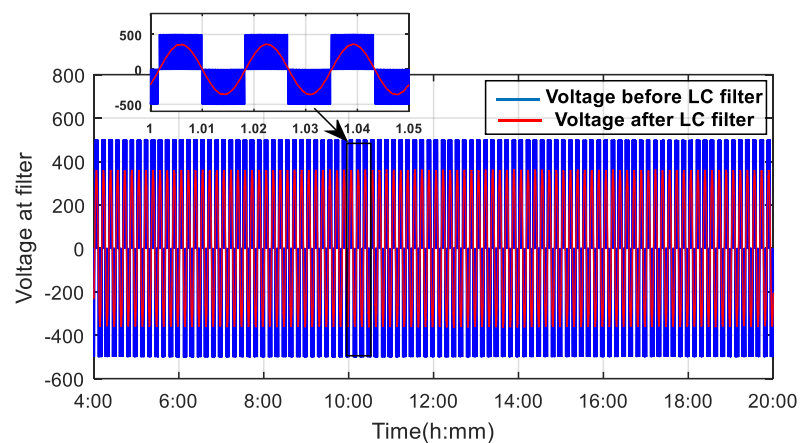

(d) Output Voltage of 3L-VSI before and after LC filter

Fig. 17. Grid side results for actual irradiance. 


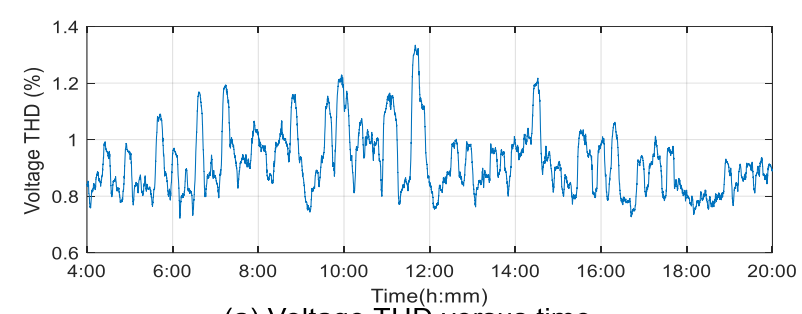

(a) Voltage THD versus time

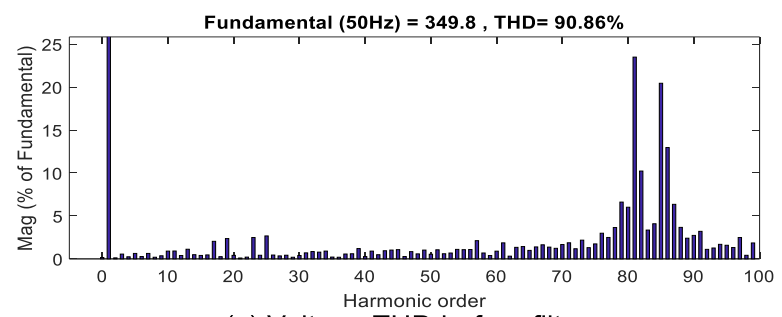

(c) Voltage THD before filter

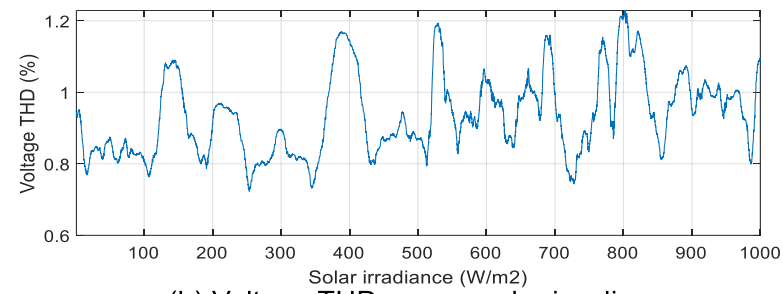

(b) Voltage THD versus solar irradiance

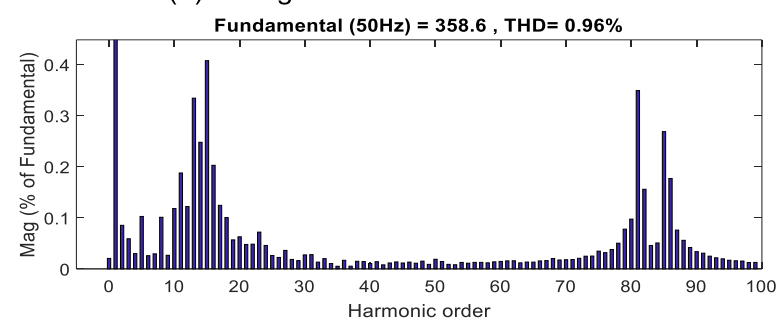

(d) Voltage THD after filter

Fig. 18. Voltage THD before and after LC filter for actual irradiance.

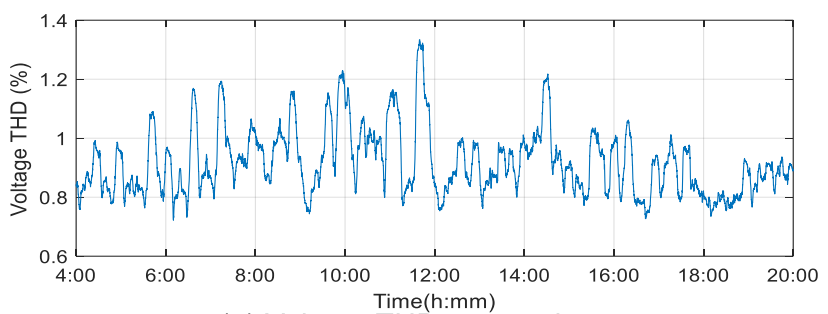

(a) Voltage THD versus time

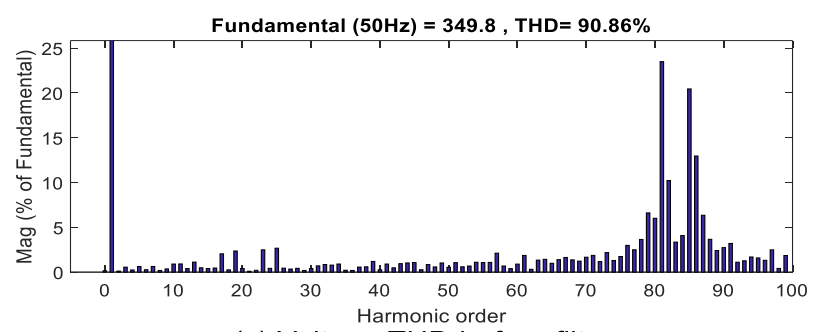

(c) Voltage THD before filter

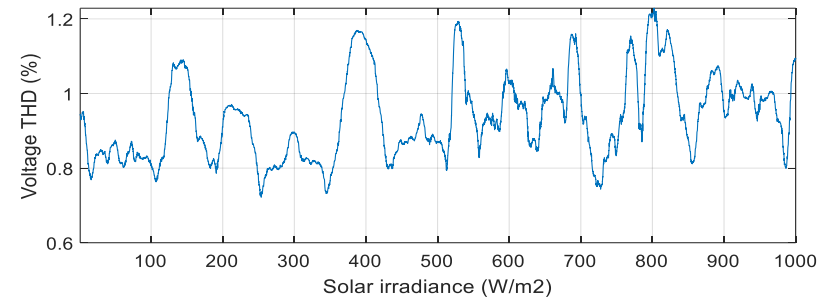

(b) Voltage THD versus solar irradiance

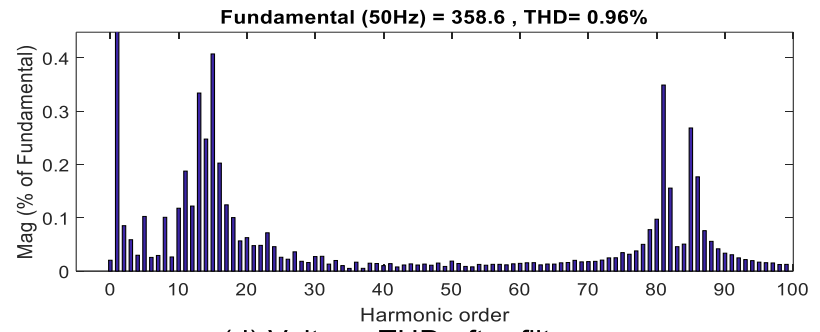

(d) Voltage THD after filter

Fig. 19. Current THD for actual irradiance.

\subsection{Cost analysis:}

Although their installation costs are high at the beginning, PV generators are cost-effective in terms of operation and maintenance. The systems become more and more efficient thanks to technological developments, and costs are gradually reduced.

Figure 20 was exported from the sunny design [12] which shows the energy yield per month and the annual energy yield of the designed PV power plants. From the figure, the annual energy yield equals to 68.627MWh. The cost analysis of a 39.78 $\mathrm{kW}$ grid-connected PV power plant is given in Table 8. Figure 21 shows yearly financial balance and payback of the considered system.

The considered system installed in October 2016 to provide energy for a textile factory generates $68.627 \mathrm{MWh}$ of energy and reaches its initial cost in 6.1 years. This significant renewable energy source bears the utmost importance in today's world where the need for and cost of energy is considerably high. In addition to its costefficiency, the system is also environmentally friendly. It does not lead to gas emission or contribute to global warming. It is observed that PV generators are significantly useful when climatic conditions are considered. 
Vol. 40, No. 1. January 2021

COST ANALYSIS OF 39.78 KW GRID CONNECTED PV SYSTEM

\begin{tabular}{|c|c|c|c|c|c|}
\hline $\begin{array}{l}\text { PV } \\
\text { Panels }\end{array}$ & \multicolumn{2}{|c|}{$\begin{array}{l}\text { STP255- } \\
20 / w d\end{array}$} & $\begin{array}{l}156 \\
\text { PCS }\end{array}$ & $\begin{array}{l}6.2 \\
\text { EGP/W } \\
\text { att }\end{array}$ & $\begin{array}{l}246,63 \\
6 \text { EGP }\end{array}$ \\
\hline Support & \multicolumn{2}{|c|}{ Aluminum } & $\begin{array}{l}156 \\
\text { PCS }\end{array}$ & $\begin{array}{l}1200 \\
\mathrm{EGP} / \mathrm{K} \\
W\end{array}$ & $\begin{array}{l}47,736 \\
\text { EGP }\end{array}$ \\
\hline Inverter & \multicolumn{2}{|c|}{$\begin{array}{l}\text { STP } \\
20000 T L-30\end{array}$} & $2 \mathrm{PCS}$ & $\begin{array}{l}24,000 \\
\text { EGP/P } \\
\text { CS }\end{array}$ & $\begin{array}{l}48,000 \\
\text { EGP }\end{array}$ \\
\hline \multirow[t]{2}{*}{ Cable } & $A C$ & $\begin{array}{l}C X 1- \\
4 \times 16 \\
m m 2\end{array}$ & $100 \mathrm{~m}$ & $\begin{array}{l}120 \\
\mathrm{EGP} / \mathrm{m}\end{array}$ & $\begin{array}{l}1,200 \\
\text { EGP }\end{array}$ \\
\hline & $\begin{array}{l}D \\
C\end{array}$ & $\begin{array}{l}K P E \\
6 m m 2\end{array}$ & $1,000 \mathrm{~m}$ & $\begin{array}{l}8 \\
\mathrm{EGP} / \mathrm{m}\end{array}$ & $\begin{array}{l}8,000 \\
\text { EGP }\end{array}$ \\
\hline \multirow[t]{3}{*}{$\begin{array}{l}\text { Protectio } \\
n\end{array}$} & \multicolumn{2}{|c|}{$\begin{array}{l}A C \\
\text { protection }\end{array}$} & SET & $\begin{array}{l}1,000 \\
\text { EGP }\end{array}$ & $\begin{array}{l}1,000 \\
\text { EGP }\end{array}$ \\
\hline & \multicolumn{2}{|c|}{$\begin{array}{l}\text { DC } \\
\text { protection }\end{array}$} & SET & $\begin{array}{l}1,500 \\
\text { EGP }\end{array}$ & $\begin{array}{l}1,500 \\
\text { EGP }\end{array}$ \\
\hline & \multicolumn{2}{|c|}{ Earthing } & SET & $\begin{array}{l}10,000 \\
\text { EGP }\end{array}$ & $\begin{array}{c}10,000 \\
\text { EGP }\end{array}$ \\
\hline \multicolumn{3}{|c|}{ Installation } & $\begin{array}{l}39.78 \\
\mathrm{~kW}\end{array}$ & $\begin{array}{l}350 \\
\text { EGP/k } \\
\text { W }\end{array}$ & $\begin{array}{l}13,923 \\
\text { EGP }\end{array}$ \\
\hline \multicolumn{3}{|l|}{ Total } & \multicolumn{3}{|c|}{377,995 EGP } \\
\hline \multicolumn{3}{|l|}{ Taxes } & $10 \%$ & \multicolumn{2}{|c|}{ 37,799.5 EGP } \\
\hline \multicolumn{3}{|c|}{ Net investment } & \multicolumn{3}{|c|}{$415,794.5$ EGP } \\
\hline \multicolumn{3}{|c|}{ System Costs $(E G P / W)$} & \multicolumn{3}{|c|}{$10.45 \mathrm{EGP} / \mathrm{W}$} \\
\hline \multicolumn{3}{|c|}{ Fixed feeding tariff } & \multicolumn{3}{|c|}{1.08 EGP } \\
\hline \multicolumn{3}{|c|}{ Annual energy yield } & \multicolumn{3}{|c|}{$68,627 \mathrm{kWh}$} \\
\hline \multicolumn{3}{|c|}{ Total yearly income } & \multicolumn{3}{|c|}{ 74,117 EGP } \\
\hline \multicolumn{3}{|c|}{ Total income (25 years) } & \multicolumn{3}{|c|}{$1,852,929$} \\
\hline \multicolumn{3}{|c|}{$\begin{array}{l}\text { Maintenance cost }(1 \\
\text { year) }\end{array}$} & \multicolumn{3}{|c|}{ 6,000 EGP } \\
\hline \multicolumn{3}{|c|}{ Net profit } & \multicolumn{3}{|c|}{ 1,702,929 EGP } \\
\hline
\end{tabular}

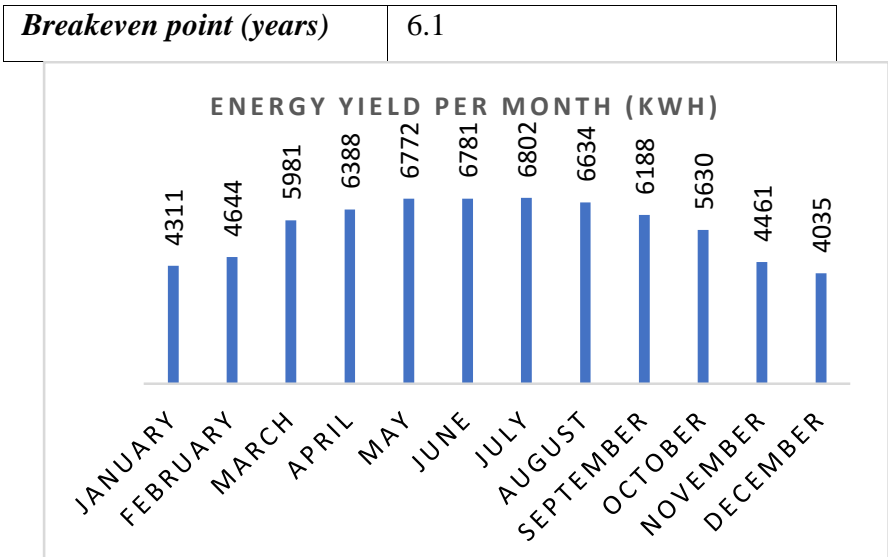

Fig. 20. Energy yield per month.

Yearly financial balance $(\times 1000 \mathrm{EGP})$

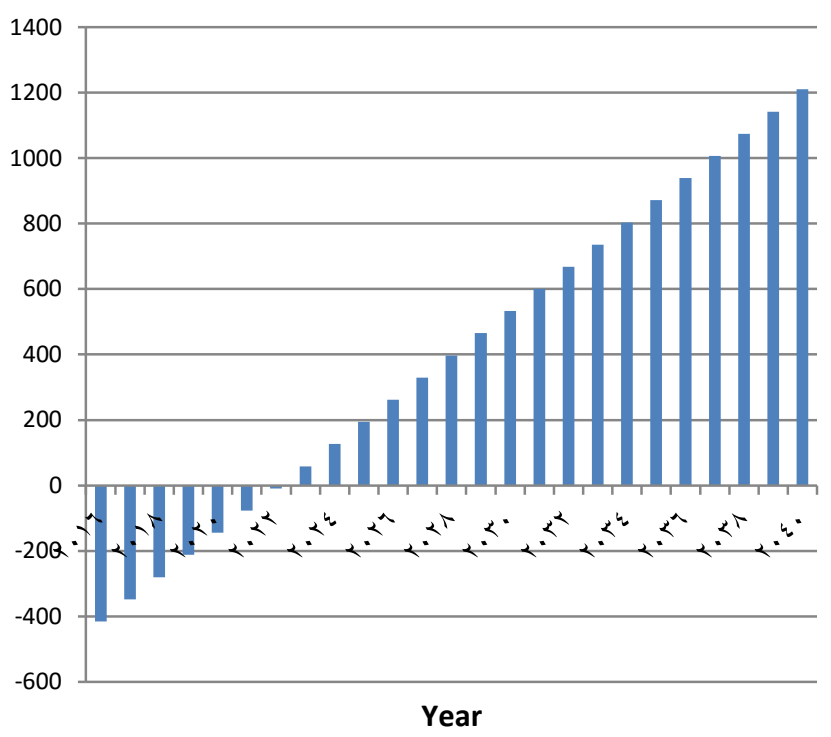

Fig. 21. Yearly financial balance. 


\section{CONCLUSION}

The power quality observations of the PV grid-connected system which is installed in Egypt have been presented. A $39.78 \mathrm{kWp}$ grid-connected PV system was simulated using Matlab/Simulink software under different solar irradiances. Measurements from the PV array under test have been analyzed and evaluated to observe the overall effect of technical requirements according to the Egyptian PV LV code of the PV grid-connected system under test and cost analysis. It has been found that a low solar irradiance has a significant impact on the power quality of the output of the PV system. The results show that the active power produced by the PV system causes a voltage rise, voltage flicker, and power factor reduction, which may create severe problems with the system components. The system installed in October 2016 and able to provide the energy for a textile factory and also the system generates $68.288 \mathrm{MWh}$ of energy and reaches its initial cost in 6.137 years.

\section{REFERENCES}

[1] Bae, Y., T.-K. Vu, and R.-Y.J.I.T.o.E.C. Kim Implemental control strategy for grid stabilization of grid-connected PV system based on German grid code in symmetrical low-to-medium voltage network. 2013. 28(3): p. 619-631.

[2] E Caamaño-Martín, H. Laukamp et al., Interaction between photovoltaic distributed generation and electricity networks. Progress in Photovoltaics: research and applications, 2008. 16(7): p. 629-643.

[3] El kholy, A., et al., Experimental evaluation of $8 \mathrm{~kW}$ grid-

connected photovoltaic system in Egypt. Journal of Electrical Systems and Information Technology. 3(2): p. 217-229.
[4] Micheli, D., et al., Analysis of the outdoor performance and efficiency of two grid connected photovoltaic systems in northern Italy. 2014. 80: p. 436-445.

[5] Kageyama, H., et al. Measurement of inrush-current waveforms for modeling reactance characteristics of pv modules. in 26th European Photovoltaic Solar Energy Conference and Exhibition. 2011.

[6] Sharma, S. and B. Parekh. Impact of pvps (photovoltaic power system) connection to grid in urban areas. in National Conference on Recent Trends in Engineering \& Technology. 2011.

[7] Wang, B., et al. Dynamic modeling and transient fault analysis of feeder in distribution system with MW PV substation. in Universities Power Engineering Conference (UPEC), $2010 \quad$ 45th International. 2010. IEEE.

[8] Farhoodnea, M., et al., Power quality analysis of grid-connected photovoltaic systems in distribution networks. Przeglad Elektrotechniczny (Electrical Review), ISSN 0033-2097, 2013. 89(2), 2013: p. 208-213.

[9] Farhoodnea, M., et al., An enhanced method for contribution assessment of utility and customer harmonic distortions in radial and weakly meshed distribution systems. International Journal of Electrical Power \& Energy Systems, 2012. 43(1): p. 222-229.

[10] Hassan, M. Performance Analysis of GridConnected PV System. in 18th International Middle-East Power System Conference (MEPCON'16), Helwan, Egypt, December 27-29. 2016.

[11] Halpin, S. Revisions to ieee standard 5191992. in IEEE PES transmission and distribution conference and exhibition. 2006. [12] https://www.sunnydesignweb.com/sdweb/\#/ Home, Access 21 November 2019. 


\section{تحليل أداء نظام الطاقة الثمسية المتصل بالثبكة: دراسة حالة في مصر}

الملخص:

أصبحت مصادر الطاقة المتجددة ، وخاصة الأنظمة الكهروضوئية ، مصادر أكثر أهمية للطاقة ، مما جذب اهتمام تجاري كبير • ومع ذلك ، فإن توصيل أنظمة الطاقة الكهروضوئية بشبكات القوى الكهربية الموحدة قد يسبب العديد من المشكلات لثبكات التوزيع عند التشغيل. تعتمد شدة هذه المشكلات بشكل مباشر على النسبة المئوية للقوى الكهربية المولدة من خلايا الطاقة الثمسية والموصلة الى الشبكة وايضا جغرافيا التثبيت. وبالتالي ، فإن معرفة التأثير المحتمل للأنظمة الكهروضوئية الصغيرة المتصلة بالشبكة على شبكات التوزيع يمكن أن توفر حلوًا ممكنة قبل التطبيقات العملية. تعتمد الطاقة الكهبائية المولدة من محطات الطاقة الثمسية (PV) بشكل رئيسي على الظروف المناخية. لذلك ، يجب أن تزود هذه المحطات المتصلة بالثبكة بنظام التحكم لتلبية استجابة سريعة لتغيير الإشعاع الثمسي. تتضمن هذه الدراسة تحليل أداء للبيانات والقياسات الفعلية من موقع النظام المتصل بالشبكة وفقًا للكود المصري PV-LV لعام ع ا. ب ، والمحاكاة باستخدام برنامج

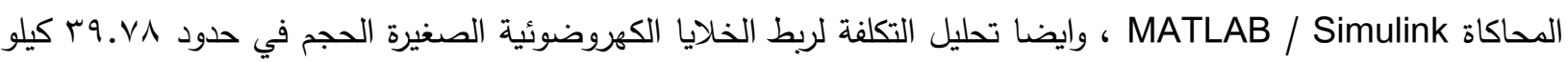
واط بشبكات التوزيع. وايضا يتم قياس مؤاشرات جودة الطاقة من محطة الطاقة الشمسية المثبتة في مدرسة Holy Family

$$
\begin{aligned}
& \text { School } \\
& \text { الياف اللب من ا.. ٪ إلى ع.. ٪. }
\end{aligned}
$$

